\title{
Ciprofloxacin triggers the apoptosis of human triple-negative breast cancer MDA-MB-231 cells via the $\mathrm{p53/Bax} / \mathrm{Bcl}-2$ signaling pathway
}

\author{
ARTUR BEBEROK, DOROTA WRZEŚNIOK, JAKUB ROK, ZUZANNA RZEPKA, \\ MICHALINA RESPONDEK and EWA BUSZMAN \\ Department of Pharmaceutical Chemistry, School of Pharmacy with the Division of Laboratory Medicine, \\ Medical University of Silesia, 41-200 Sosnowiec, Poland
}

Received October 18, 2017; Accepted January 22, 2018

DOI: $10.3892 /$ ijo. 2018.4310

\begin{abstract}
Fluoroquinolone antibiotics induce cytotoxicity in various cancer cell lines and may therefore represent a potentially important source of novel anticancer agents. The aim of the present study was to examine the effect of ciprofloxacin on the viability, redox balance, apoptosis, expression of p53, Bax and Bcl-2, cell cycle distribution and DNA fragmentation of triple-negative MDA-MB-231 breast cancer cells. The results of the present study demonstrated that ciprofloxacin decreases cell viability in a dose- and time-dependent manner. The half maximal inhibitory concentration values of ciprofloxacin in MDA-MB-231 cells following treatment for 24, 48 and $72 \mathrm{~h}$ were $0.83,0.14$ and $0.03 \mu \mathrm{mol} / \mathrm{ml}$, respectively. Furthermore, it was demonstrated that ciprofloxacin altered the redox signaling pathway, as determined by intracellular glutathione depletion. The results of Annexin V/propidium iodide staining revealed that ciprofloxacin triggered the apoptosis of MDA-MB-231 cells. Furthermore, cipfloxacin treatment stimulated the loss of the mitochondrial transmembrane potential via the Bax/Bcl-2-dependent pathway, thus inducing apoptosis. Ciprofloxacin induced cell cycle arrest at the S-phase; therefore it was hypothesized that ciprofloxacin inhibits topoisomerase II. Oligonucleosomal DNA fragmentation and the elevation of p53 expression were observed in the present study, indicating that this late-apoptotic event may be mediated by the p53-dependent pathway. Therefore, the results of the current study provide important molecular data concerning the cellular cascade, which may explain the
\end{abstract}

Correspondence to: Dr Artur Beberok, Department of Pharmaceutical Chemistry, School of Pharmacy with the Division of Laboratory Medicine, Medical University of Silesia, Jagiellońska 4, 41-200 Sosnowiec, Poland

E-mail: abeberok@sum.edu.pl

Key words: ciprofloxacin, breast cancer, cell viability, apoptosis, p53/Bax/Bcl-2 pathway cytotoxicity induced by ciprofloxacin in human triple-negative breast cancer cells, thus providing a novel insight into the therapeutic properties of this drug.

\section{Introduction}

Breast cancer is the most common cause of cancer-associated mortality in women and $~ 1.7$ million cases of breast cancer are diagnosed worldwide each year (1). Out of all breast cancer cases, $15-20 \%$ are characterized as triple-negative, which is negative for the expression of estrogen and progesterone receptors and does not exhibit amplification of the HER2/Neu gene $(2,3)$. Hormonal or trastuzumab-based therapies are generally ineffective at treating triple-negative breast cancer (TNBC); therefore, taxane, cisplatinum derivatives and bevacizumab, as well as anthracycline-based chemotherapies used alone or in combination with surgery and/or radiotherapy, remain the standard methods of treating $\operatorname{TNBC}(2,4)$. The overall survival rate of patients with TNBC is poor compared with those that have other subtypes of breast cancer (2); therefore, novel chemotherapeutic agents to treat this subtype of breast cancer are required.

DNA topoisomerases are highly specialized nuclear enzymes. By breaking and rejoining DNA strands, they overcome the DNA supercoiling that occurs during DNA replication, transcription and repair $(5,6)$. Human DNA topoisomerases are molecular targets of several classes of antineoplastic agents, including camptothecins, anthracyclines and epipodophyllotoxins, which are used to treat various types of cancer, including breast, lung, prostate and hematological cancer $(7,8)$.

Fluoroquinolones are a class of synthetic antibiotics that interact with topoisomerase II-DNA complexes and inhibit helix rejoining, resulting in the formation of double-stranded DNA breaks (9). Fluoroquinolones, including ciprofloxacin, enrofloxacin, moxifloxacin and gatifloxacin exhibit activity not only against bacterial topoisomerase II (DNA gyrase) and topoisomerase IV, but also against eukaryotic topoisomerase II $\alpha$, the analogue of DNA gyrase. Therefore, certain members of these antibiotics exhibit marked cytotoxicity in various mammalian cancer cell lines (10-15). However, it 
should be noted that certain treatments for cancer may not distinguish between tumor and non-tumor cells in patients and may therefore induce undesirable side effects, such as genotoxicity (16).

Ciprofloxacin (Fig. 1A) is a well tolerated second-generation fluoroquinolone antibiotic used to treat patients with community and hospital-acquired infections $(16,17)$. It has been suggested that ciprofloxacin is less susceptible to efflux-mediated resistance compared with conventional topoisomerase II chemotherapeutics, including doxorubicin and etoposide (18).

It is estimated that DNA topoisomerase II $\alpha(T O P 2 A)$ is frequently co-amplified with the human epidermal growth factor receptor (HER2) oncogene in $40-50 \%$ of breast cancer cases (19). This may mean that the clinical response to topoisomerase II inhibitor-based chemotherapy is more marked in patients with HER2-positive breast cancer. However, TOP $2 A$ amplification may also occur in HER2-negative breast cancer (20).

The overproduction of reactive oxygen species (ROS) and depletion of cellular antioxidants, including reduced glutathione (GSH), stimulate the induction of cancer cell apoptosis (21). Hence, strategies aiming at disrupting redox homeostasis may be used to chemosensitize tumors and may represent a novel method of treating cancer (22).

The overproduction of ROS mediates the signal transduction of apoptosis; increased levels of ROS may induce oxidative stress, loss of cell function and cellular apoptosis. ROS are also able induce lipid peroxidation and the cross-linking of thiol groups in proteins (21). Furthermore, tumors may be sensitized to chemotherapy and other antitumor treatments by inhibiting antioxidant defenses, such as NADPH or GSH, via metabolic suppression. Therefore, methods of regulating redox signaling in tumor cells may represent promising novel methods of treating cancer (22).

The overexpression of p53 deregulates regulation of the cell cycle, DNA synthesis and cell apoptosis. Stimulation of the p53 pathway is one of the mechanisms by which anticancer drugs induce the apoptosis of cancer cells (23). Several p53 downstream target gene products, such as the pro-apoptotic Bax protein, are able to mediate apoptosis; when these products are expressed in concert, apoptosis is induced (24). Mitochondrial dysfunction mediated by members of the $\mathrm{Bcl}-2$ family, including anti-apoptotic Bcl-2 and pro-apoptotic Bax, is a well known early event of apoptosis (25). p53 may also inhibit Bcl-2 expression and trigger mitochondrial apoptotic signaling by increasing levels of $\operatorname{ROS}(25,26)$.

The MDA-MB-231 cell line, is negative for the expression of the estrogen and progesterone receptors and $\mathrm{HER} 2 / \mathrm{Neu}$ amplification and is one of the most commonly studied TNCB cell lines (27).

Studies have demonstrated that ciprofloxacin induces time- and dose-dependent growth inhibition, apoptosis and modulation of the cell cycle in human colorectal (11), pancreatic (13) and human prostate (14) cancer cell lines. However, to the best of our knowledge, there have been no studies investigating the cytotoxic effect of ciprofloxacin in a TNBC cell line. Therefore, the present study investigated the impact of ciprofloxacin on the viability, redox balance and apoptosis of MDA-MB-231 breast cancer cells.

\section{Materials and methods}

Reagents. Ciprofloxacin hydrochloride was obtained from Sigma-Aldrich; Merck KGaA (Darmstadt, Germany). Dulbecco's modified Eagle's medium (DMEM), fetal bovine serum (FBS), penicillin, streptomycin, amphotericin B and trypsin/EDTA were all purchased from Cytogen GmbH (Wetzlar, Germany). WST-1 was purchased from Roche Diagnostics GmbH (Mannheim, Germany). Solution 3 (used in the fixed cell-cycle-DAPI assay), consisting of DAPI $(1 \mu \mathrm{g} / \mathrm{ml})$ and Triton X-100 (0.1\%) in PBS; solution 7 (used in the mitochondrial potential assay), consisting of JC-1 $(200 \mu \mathrm{g} / \mathrm{ml})$ in dimethyl sulfoxide (DMSO); solution 8 (used in the mitochondrial potential assay) consisting of DAPI $(1 \mu \mathrm{g} / \mathrm{ml})$ in PBS; solution 5 (used to measure intracellular GSH levels) consisting of VitaBright- $48^{\mathrm{TM}}$ (VB-48 $\left.{ }^{\mathrm{TM}} ; 400 \mu \mathrm{g} / \mathrm{ml}\right)$, propidium iodide (PI; $500 \mu \mathrm{g} / \mathrm{ml}$ ) and acridine orange (AO; $1.2 \mu \mathrm{g} / \mathrm{ml})$ in DMSO; solution 15 consisting of Hoechst 33342 $(500 \mu \mathrm{g} / \mathrm{ml})$; and solution 16 consisting of PI $(500 \mu \mathrm{g} / \mathrm{ml})$ were all purchased from ChemoMetec (Allerod, Denmark). Annexin V-CF488A conjugate and Annexin V binding buffer were obtained from Biotium, Inc. (Fremont, CA, USA).

MDA-MB-231 cell culture. The human epithelial metastatic breast cancer cell line MDA-MB-231 was purchased from the ATCC (ATCC ${ }^{\circledR}$ HTB-26 ${ }^{\text {TM }}$; Manassas, VA, USA). Cells were cultured in DMEM supplemented with $10 \%$ FBS, penicillin $(10,000 \mathrm{U} / \mathrm{ml})$, streptomycin $(10 \mathrm{mg} / \mathrm{ml})$ and amphotericin $\mathrm{B}$ $(0.25 \mathrm{mg} / \mathrm{ml})$ at $37^{\circ} \mathrm{C}$ in $5 \% \mathrm{CO}_{2}$.

Cell viability assay. The viability of MDA-MB-231 cells was evaluated using a WST-1-based microplate colorimetric assay following a previously described protocol (28). Briefly, 2,500 cells/well were pre-incubated in DMEM for $24 \mathrm{~h}$. Subsequently, the medium was replaced with different concentrations of ciprofloxacin $(0.0001,0.001,0.01,0.05,0.1$, 0.5 and $1.0 \mu \mathrm{mol} / \mathrm{ml}$ ) and cells were incubated with the drug for 24,48 or $72 \mathrm{~h}$. WST-1 was added $3 \mathrm{~h}$ prior to the end of the incubation periods. The absorbance of samples was measured at $440 \mathrm{~nm}$ with a reference wavelength of $650 \mathrm{~nm}$ using a microplate reader. The viability of MDA-MB-231 cells that were not treated with ciprofloxacin (controls) were normalized to $100 \%$ for each assay and the results of the experiments were expressed as the percentage of the controls. The assay was performed in three independent experiments in triplicate.

Assessment of intracellular GSH levels. GSH levels in MDA-MB-231 cells were measured using the NucleoCounter ${ }^{\circledR}$ NC-3000 ${ }^{\mathrm{TM}}$ (ChemoMetec) fluorescence image cytometer following a previously reported protocol (28). MDA-MB-231 cells were seeded in T-75 flasks ( $2 \times 10^{6}$ cells/flask) and pretreated in DMEM for $24 \mathrm{~h}$. Subsequently, the medium was replaced with various concentrations of ciprofloxacin $(0.01,0.1$ and $1.0 \mu \mathrm{mol} / \mathrm{ml}$ ) and cells were incubated with the drug for a further $24 \mathrm{~h}$. Samples were treated with solution 5 according the manufacturer's protocol and analysis was conducted using NucleoView NC-3000 software, version 1.4 (ChemoMetec). The assay was performed in three independent experiments in triplicate.

Annexin V assay. During apoptosis, the presence of phosphatidylserine on the exterior surface of the plasma membrane 
may be detected using Annexin V-fluorescein isothiocyanate (Annexin V-FITC). This assay is combined with the analysis of exclusion of plasma membrane integrity (PI probe). MDA-MB-231 cells were seeded in T-75 flasks at a density of $2 \times 10^{6}$ cells/flask for $24 \mathrm{~h}$. Cells were then treated with various concentrations of ciprofloxacin $(0.01,0.1$ and $1.0 \mu \mathrm{mol} / \mathrm{ml})$. Following $24 \mathrm{~h}$ incubation, cells were harvested by trypsinization and counted using the NucleoCounter image cytometer. A total of $3.0 \times 10^{5}$ cells were suspended in $100 \mu 1$ Annexin V binding buffer. For each sample, $2 \mu \mathrm{l}$ Annexin V-CF 488A conjugate and $2 \mu 1$ solution 15 (Hoechst 33342, final concentration $10 \mu \mathrm{g} / \mathrm{ml}$ ) were added and samples were incubated at $37^{\circ} \mathrm{C}$ for $15 \mathrm{~min}$ using a heating block. Stained cells were then centrifuged at $400 \times \mathrm{g}$ at room temperature for $5 \mathrm{~min}$ and washed twice with Annexin V binding buffer. Cell pellets were then resuspended in $100 \mu 1$ Annexin $\mathrm{V}$ binding buffer supplemented with solution $16(10 \mu \mathrm{g} / \mathrm{ml} \mathrm{PI})$ and analyzed immediately using the fluorescence image cytometer. Scatter-plots were used to determine the proportion of healthy cells (Annexin V-negative/PI-negative cells), early apoptotic cells (Annexin V-positive/PI-negative cells) and late apoptotic cells (Annexin V-positive/PI-positive cells). NucleoView NC-3000 software, version 1.4. was used for data analysis. The assay was performed in three independent experiments in triplicate.

Mitochondrial membrane potential assay. The mitochondrial transmembrane potential was measured using the NucleoCounter NC-3000 fluorescence image cytometer following a previously described protocol (28). MDA-MB-231 cells were seeded in T-75 flasks $\left(2 \times 10^{6}\right.$ cells/flask $)$ and pretreated in DMEM for $24 \mathrm{~h}$. Subsequently, the medium was replaced with different concentrations of ciprofloxacin $(0.01,0.1$ and $1.0 \mu \mathrm{mol} / \mathrm{ml})$ and cells were incubated for 24 and $48 \mathrm{~h}$. Samples were stained with solutions 7 at $37^{\circ} \mathrm{C}$ for $15 \mathrm{~min}$. At the end of analysis, cell pellets were resuspended in $250 \mu \mathrm{l}$ solution 8 and analyzed immediately using NucleoView NC-3000 software, version 1.4 (ChemoMetec). The assay was performed in three independent experiments in triplicate.

Quantitative determination of p53, Bax and Bcl-2 proteins. The expression of p53, Bax and Bcl-2 in cell lysates following treatment with different concentrations of ciprofloxacin (0.01, 0.1 and $1.0 \mu \mathrm{mol} / \mathrm{ml}$ ) for $24 \mathrm{~h}$ were measured using human p53 (Biovendor, Brno, Czech Republic), human Bax (Enzo Biochem, New York, NY, USA) and human Bcl-2 (Biovendor) enzyme-linked immunosorbent assay (ELISA) kits (cat. nos. RAF082R, ADI-900-138 and RAF005R, respectively), following the manufacturer's protocol. The expression of p53, Bax and Bcl-2 were normalized to total protein content and expressed as percentages of the controls (lysates of cells that were not treated with ciprofloxacin). Total protein concentration in each lysate was determined using the Pierce BCA Protein assay kit (cat. no. 23225; Thermo Fisher Scientific, Inc., Waltham, MA, USA), with bovine serum albumin as a standard. The assay was performed in three independent experiments in triplicate.

Fixed cell cycle-DAPI assay. Cell cycle analysis of MDA-MB-231 cells was performed using the NucleoCounter
NC-3000 fluorescence image cytometer following a previously described protocol (28). In brief, MDA-MB-231 cells were seeded in T-75 flasks $\left(2 \times 10^{6}\right.$ cells/flask) and pretreated in growth medium for $24 \mathrm{~h}$. The medium was then replaced with different concentrations of ciprofloxacin $(0.01,0.1$ and $1.0 \mu \mathrm{mol} / \mathrm{ml}$ ) and cells were incubated with the drug for a further $24 \mathrm{~h}$. Cells were fixed with $70 \%$ cold-ethanol at $4^{\circ} \mathrm{C}$ for $24 \mathrm{~h}$, stained with solution 3 containing DAPI for $5 \mathrm{~min}$ at $37^{\circ} \mathrm{C}$ and analyzed using the NucleoView NC-3000 software, version 1.4. The assay was performed in three independent experiments in triplicate.

Statistical analysis. For all experiments, at least three separate experiments $(n=3)$ were performed in triplicate and the results are presented as the mean \pm standard error of the mean. Statistical analysis was performed using GraphPad Prism 6.01 (GraphPad Software, Inc., La Jolla, CA, USA). Differences among groups were assessed using one-way analysis of variance followed by Dunnett's test. $\mathrm{P}<0.05$ was determined to indicate a significant difference.

\section{Results}

Ciprofloxacine reduces $M D A-M B-231$ cell viability. To investigate the effect of ciprofloxacin on the viability of human MDA-MB-231 breast cancer cells, a WST-1 assay was performed. The results demonstrated that ciprofloxacin significantly decreased cell viability in a dose- and time-dependent manner (Fig. 1). Incubation with $0.01-1 \mu \mathrm{mol} / \mathrm{ml}$ ciprofloxacin for $24 \mathrm{~h}$ significantly decreased MDA-MB-231 cell viability by between $24 \pm 3$ and $53 \pm 4 \%$, compared with the control (Fig. 1B). The cytotoxic effects of ciprofloxacin increased following an increase in the incubation period to $48 \mathrm{~h}$, when the viability of MDA-MB-231 cells treated with $1.0 \mu \mathrm{mol} / \mathrm{ml}$ ciprofloxacin decreased to $33 \pm 6 \%$ compared with the control. Following $72 \mathrm{~h}$ incubation, a significant decrease in cell viability was observed following incubation with all concentrations of ciprofloxacin (Fig. 1B). The exposure of cells to $0.0001-1.0 \mu \mathrm{mol} / \mathrm{ml}$ ciprofloxacin resulted in a decrease of cell viability of between $15 \pm 3$ and $74 \pm 4 \%$, compared with the control.

The strongest decrease in cell viability following incubation for 24, 48 and $72 h$ was observed following treatment with $1.0 \mathrm{\mu mol} / \mathrm{ml}$ ciprofloxacin. Furthermore, for MDA-MB-231 cells treated with ciprofloxacin for 24,48 and $72 \mathrm{~h}$, the concentrations of ciprofloxacin that decreased cell viability by $50 \%$ were $0.83,0.14$ and $0.03 \mu \mathrm{mol} / \mathrm{ml}$, respectively.

Ciprofloxacin induces morphological changes in MDA-MB-231 cells. Morphological changes of MDA-mB-231 cells were determined using a light-inverted microscope at a magnification of x100. As presented in Fig. 2A, untreated MDA-MB-231 cells grew adherently in culture flask and had a regular shape and size. Treatment with the lowest concentration of ciprofloxacin $(0.01 \mu \mathrm{mol} / \mathrm{ml})$ did not affect the morphology of MDA-MB231 cells (Fig. 2B). By contrast, cells treated with higher concentrations of ciprofloxacin $(0.1$ and $1.0 \mu \mathrm{mol} / \mathrm{ml})$ for $24 \mathrm{~h}$ lost their shape, became round and start to detach from the flask (Fig. 2C and D). A decrease in the number of cells, as well as a loss in cell-cell contact was also observed. 


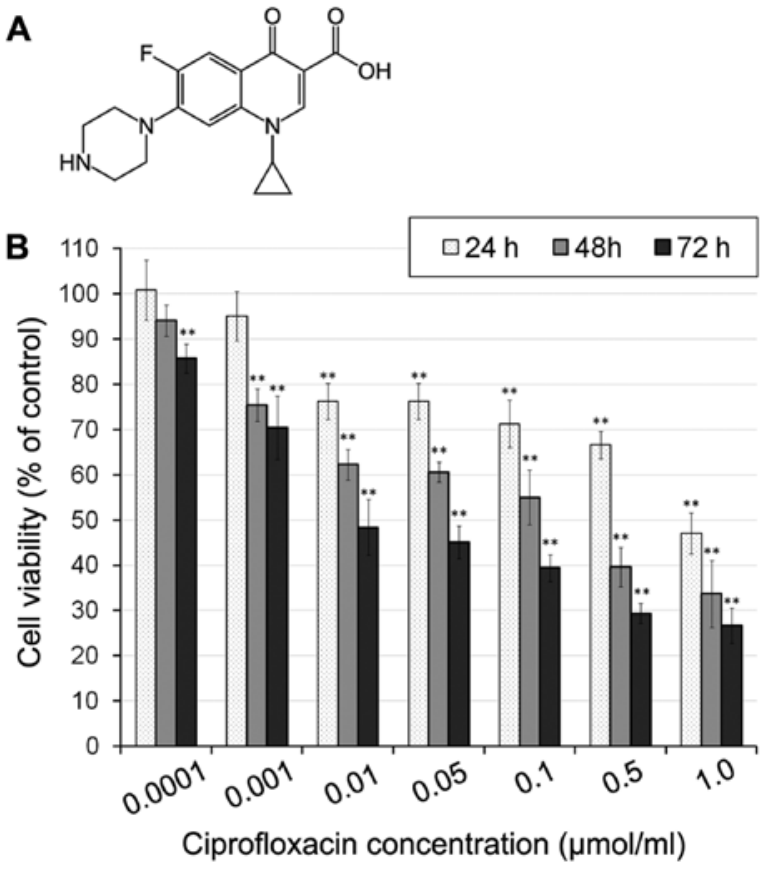

Figure 1. (A) The chemical structure of ciprofloxacin. (B) The effect of ciprofloxacin on the viability of MDA-MB-231 breast cancer cells. Cells were treated with various concentrations of ciprofloxacin $(0.0001-1.0 \mu \mathrm{mol} / \mathrm{ml})$ for 24, 48 and $72 \mathrm{~h}$ and examined using a WST-1 assay. Data are expressed as $\%$ of the controls. All results are presented as the mean values \pm standard error of the mean from three independent experiments $(n=3)$ performed in triplicate. ${ }^{* *} \mathrm{P}<0.005$ vs. control.

The effect of ciprofloxacin on cellular GSH levels. There is a strong correlation between cellular GSH depletion and the progression of apoptosis (22). In the present study, MDA-MB-231 cells were stained with three different reagents: A stain for all nucleated cells (AO), a stain staining dead cells alone (PI) and VB-48 ${ }^{\mathrm{TM}}$, a stain that stained all viable cells in an intensity-dependent manner dependent on GSH levels. The results indicated that ciprofloxacin decreased GSH levels in MDA-MB-231 cells (Fig. 3A and B). Following the exposure of MDA-MB-231 cells to $0.01,0.1$ and $1.0 \mu \mathrm{mol} / \mathrm{ml}$ ciprofloxacin for $24 \mathrm{~h}$, the percentage of PI-negative/VB- $48^{\mathrm{TM}}$ negative cells exhibiting low levels of GSH increased from $13 \%$ (control) to $16 \pm 2,28 \pm 4$ and $51 \pm 5 \%$, respectively. Treatment of MDA-MB-231 cells with the highest concentration of ciprofloxacin $(1.0 \mu \mathrm{mol} / \mathrm{ml})$ for $24 \mathrm{~h}$ increased the percentage of PI-positive cells (dead cells) from $16 \pm 2 \%$ (control) to $29 \pm 3 \%$. The exposure of cells to lower concentrations of ciprofloxacin $(0.01$ and $0.1 \mu \mathrm{mol} / \mathrm{ml}$ ) had no significant effect on the percentage of PI positive cells compared with the control (Fig. 3A). According to the quantitative analysis of image cytometry data (Fig. 3B), 24-h incubation of MDA-MB-231 cells with the drug in concentration of $1.0 \mu \mathrm{mol} / \mathrm{ml}$ resulted in a dramatic increase in the ratio of viable cells with low GSH levels to viable cells with high GSH levels.

Ciprofloxacin induces the apoptosis of MDA-MB-231 cells. Cell apoptosis was estimated using an Annexin V assay. Phosphatidylserine, which is normally located in the inner leaflet of the plasma membrane, is exported to the outer plasma membrane leaflet during apoptosis. Annexins are a group of cellular proteins that bind to phospholipids, such as

\section{A Control}

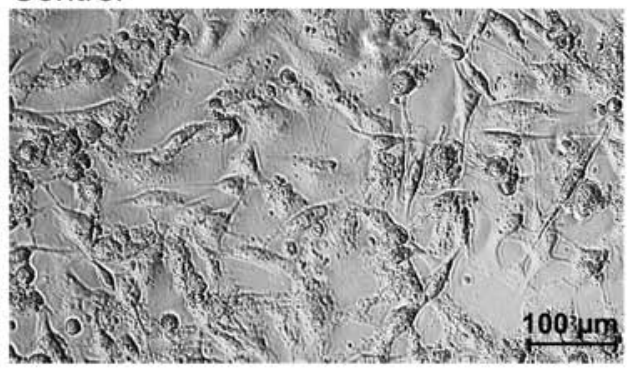

B Ciprofloxacin $0.01(\mu \mathrm{mol} / \mathrm{ml})$

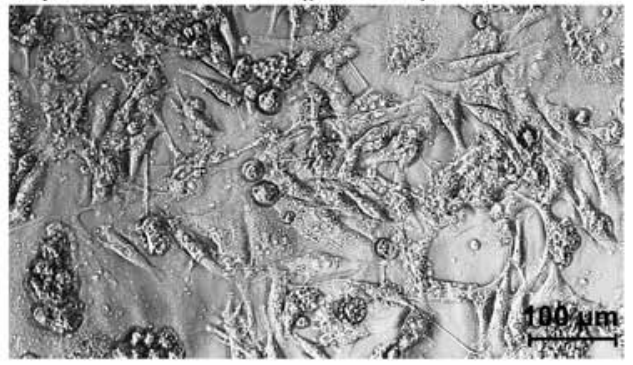

C Ciprofloxacin $0.1(\mu \mathrm{mol} / \mathrm{ml})$

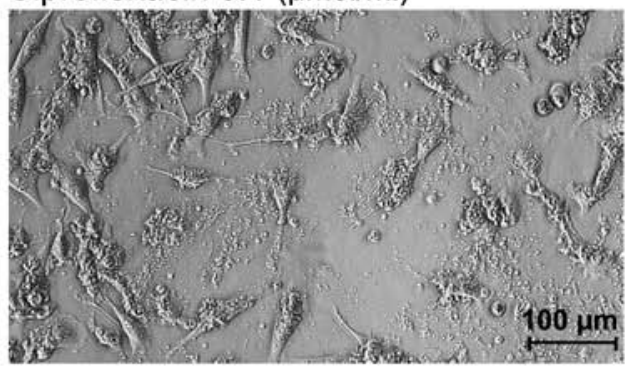

D Ciprofloxacin $1.0(\mu \mathrm{mol} / \mathrm{ml})$

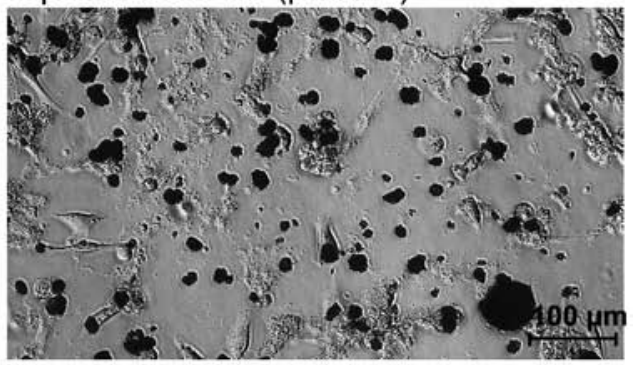

Figure 2. Ciprofloxacin induces morphological changes in MDA-MB-231 breast cancer cells. (A) Control MDA-MB-231 cells; MDA-MB-231 cells treated with (B) $0.01 \mu \mathrm{mol} / \mathrm{ml}$, (C) $0.1 \mu \mathrm{mol} / \mathrm{ml}$ and (D) $1.0 \mu \mathrm{mol} / \mathrm{ml} \mathrm{cip-}$ rofloxacin for $24 \mathrm{~h}$. Cells were observed under light inverted microscope Eclipse TS100F (Nikon) at a magnification of x100. Scale bar, $100 \mu \mathrm{m}$.

phosphatidylserine (26). By conjugating a fluorescent label to Annexin $\mathrm{V}$ it is possible to identify and quantify apoptotic cells. Annexin V also binds to phosphatidylserine in late apoptotic cells, but as the membrane integrity of these cells is lost, they may be distinguished from early apoptotic cells using PI. The exposure of MDA-MB-231 cells to ciprofloxacin induced apoptosis (Fig. 4). Following treatment of cells with 0.01 and $0.1 \mu \mathrm{mol} / \mathrm{ml}$ ciprofloxacin for $24 \mathrm{~h}$, the proportion of early apoptotic (Annexin V-positive/PI-negative) cells increased from $8 \pm 2 \%$ (control) to $14 \pm 3 \%$. The increase in apoptosis was significant following the exposure of cells to the highest concentration of ciprofloxacin $(1.0 \mu \mathrm{mol} / \mathrm{ml})$; the percentage of early apoptotic cells increased from $8 \pm 2 \%$ (control) to 


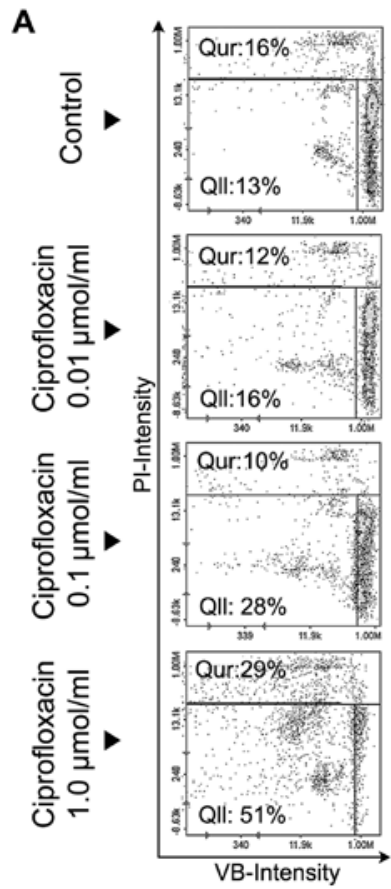

\section{B $\square$ Cells with low GSH level}

$\square$ Cells with high GSH level

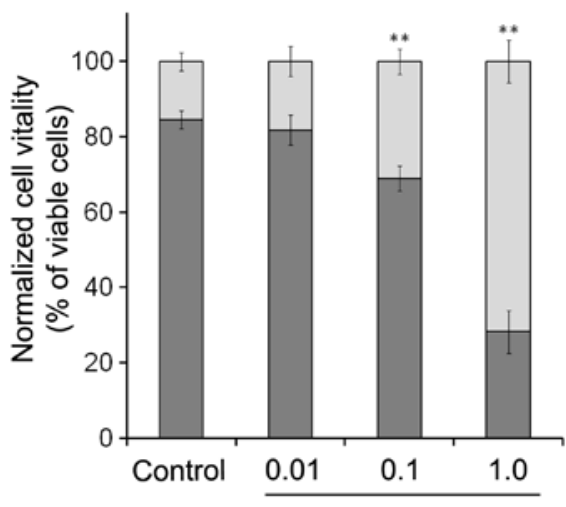

Ciprofloxacin concentration $(\mu \mathrm{mol} / \mathrm{ml})$

Figure 3. Analysis of cellular GSH level in MDA-MB-231 cells following treatment with ciprofloxacin. (A) Scatter plots presenting changes in GSH, as well as levels of dead (PI-positive cells) cells following exposure to $0.01,0.1$ and $1.0 \mu \mathrm{mol} / \mathrm{ml}$ ciprofloxacin for $24 \mathrm{~h}$. Graphs are representative of three independent experiments with similar results. (B) The effect of ciprofloxacin on cellular GSH levels in MDA-MB-231 cells. Cells were treated with $0.01,0.1$ and $1.0 \mu \mathrm{mol} / \mathrm{ml}$ ciprofloxacin for $24 \mathrm{~h}$. The results are presented as the mean \pm standard error of the mean from three independent experiments (n=3) performed in triplicate. ${ }^{* *} \mathrm{P}<0.005$ vs. the control. Qur, dead cells; Q11, cells exhibiting low levels of GSH; GSH, glutathione; PI, propidium iodide.

A

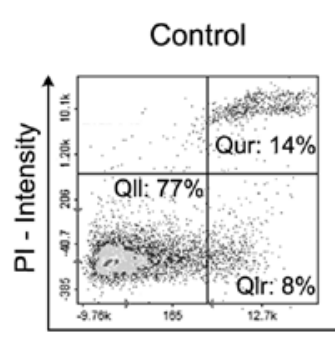

Ciprofloxacin

$$
0.01 \mu \mathrm{mol} / \mathrm{ml}
$$

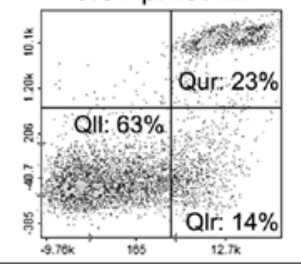

Annexin V - Intensity

B

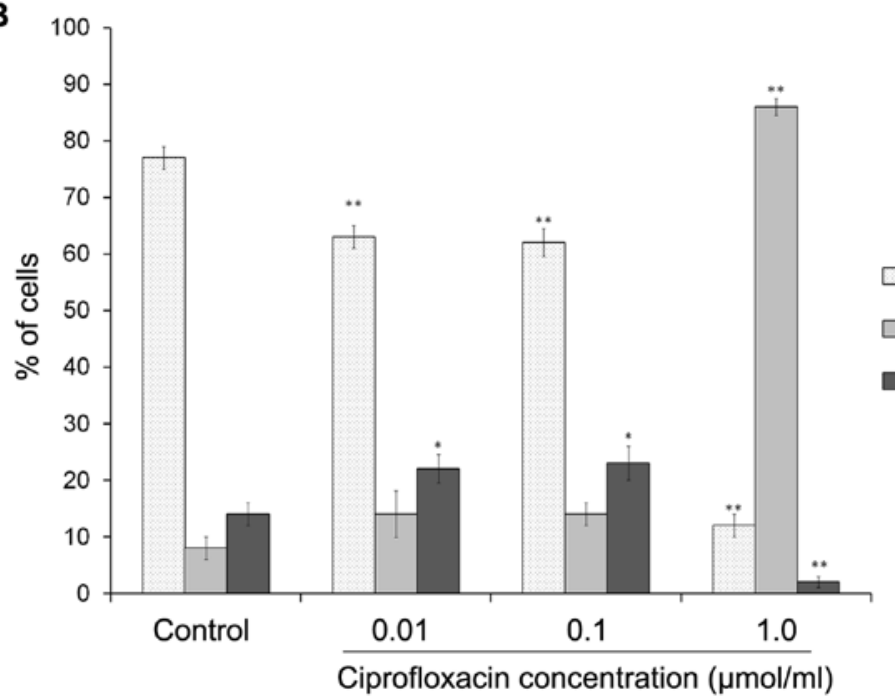

Figure 4. Ciprofloxacin induces apoptosis in MDA-MB-231 cells. (A) Scatter plots presenting changes in the Annexin V-CF488A/PI intensity of MDA-MB-231 cells treated with $0.01,0.1$ and $1.0 \mu \mathrm{mol} / \mathrm{ml}$ ciprofloxacin for $24 \mathrm{~h}$. The presented graphs are representative of three independent experiments. (B) The effect of ciprofloxacin on the apoptosis in MDA-MB-231 cells. Cells were treated with $0.01,0.1$ and $1.0 \mu \mathrm{mol} / \mathrm{ml}$ ciprofloxacin for $24 \mathrm{~h}$. The results are presented as the mean \pm standard error of the mean from three independent experiments $(n=3)$ performed in triplicate are presented. ${ }^{*} \mathrm{P}<0.05$ and ${ }^{* *} \mathrm{P}<0.005$ vs. corresponding controls. Q11, Annexin V-negative/PI-negative (healthy) cells; Qlr, Annexin V-positive/PI-negative (early apoptotic) cells; Qur, Annexin V-positive/PI-positive (late apoptotic) cells; PI, propidium iodide. 
$86 \pm 4 \%$. The treatment of MDA-MB-231 cells with 0.01 and $0.1 \mu \mathrm{mol} / \mathrm{ml}$ ciprofloxacin significantly increased the percentages of late apoptotic (Annexin V-positive/PI-positive) cells by $\sim 9 \pm 2 \%$ compared with the controls. However, treatment with $1.0 \mu \mathrm{mol} / \mathrm{ml}$ ciprofloxacin significantly decreased the proportion of late apoptotic cells compared with the control (Fig. 4B).

The effect of ciprofloxacin on the mitochondrial membrane potential in MDA-MB-231 cells. Dysregulation of the mitochondrial potential is an event that occurs early on in apoptosis (26). To detect apoptosis-associated alterations in the mitochondrial membrane in ciprofloxacin-treated breast cancer cells, staining with the lipophilic cationic dyes JC-1 and DAPI were performed, followed by image cytometric analysis. In polarized (healthy) cells, the negative charge established by the intact mitochondrial membrane potential facilitates the accumulation of JC-1 in the mitochondrial matrix, whereas in depolarized (early-apoptotic) cells, JC-1 localizes to the cytosol in its monomeric form (26). Cellular JC-1 aggregates and monomers were detected as red and green fluorescence, respectively. A decrease in the red/green fluorescence intensity ratio indicated the induction of apoptosis and mitochondrial depolarization. Late-apoptotic cells were detected as blue fluorescent (DAPI-positive) cells (Fig. 5A). Following image cytometric analysis (Fig. 5B), the percentages of mitochondrial membrane depolarized cells following treatment with 0.01 , 0.1 and $1.0 \mu \mathrm{mol} / \mathrm{ml}$ ciprofloxacin for $24 \mathrm{~h}$ was significantly increased and determined to be $46 \pm 4,51 \pm 5$ and $32 \pm 3 \%$, respectively, compared with $16 \pm 2 \%$ in control cells. The effect was markedly increased following an increase in the incubation time to $48 \mathrm{~h}$; the proportions of mitochondrial membrane depolarized cells following treatment with $0.01,0.1$ and $1.0 \mu \mathrm{mol} / \mathrm{ml}$ ciprofloxacin were $62 \pm 4,67 \pm 2$ and $56 \pm 4 \%$, while the value determined for the control was $17 \pm 2 \%$. The results indicate that ciprofloxacin increases the proportion of membrane-depolarized cells in a dose- and time-dependent manner.

A significant increase in blue DAPI fluorescence was observed following exposure of MDA-MB-231 cells to $1.0 \mu \mathrm{mol} / \mathrm{ml}$ ciprofloxacin compared with the control, indicating the induction of late apoptosis. The percentage of late apoptotic (DAPI-positive) cells were $57 \pm 3$ and $46 \pm 2 \%$ following 24 and $48 \mathrm{~h}$ incubation, respectively. The values determined for the controls were $7 \pm 1$ and $8 \pm 2 \%$, respectively.

The effect of ciprofloxacin on the expression of apoptotic proteins in MDA-MB-231 cells. To characterize the signaling pathways involved in ciprofloxacin-induced apoptosis, the expression of $\mathrm{p} 53$, Bax and Bcl-2 proteins was measured. $\mathrm{p} 53$ is a tumor suppressor protein, which can induce apoptosis in response to various stress signals, including irradiation, DNA damage and chemotherapeutic agents (29). The results of ELISA demonstrated that ciprofloxacin significantly enhanced the expression of p53 in a concentration-dependent manner (Fig. 6A). Following exposure of MDA-MB-231 cells to $0.01,0.1$ and $1.0 \mu \mathrm{mol} / \mathrm{ml}$ ciprofloxacin for $24 \mathrm{~h}$, the expression of p53 increased by $24 \pm 3,34 \pm 2$ and $61 \pm 5 \%$, respectively, compared with the controls.

The Bcl-2 protein family serves an important role in mitochondria-dependent apoptosis and regulates the mitochondrial membrane potential. Bax proteins are pro-apoptotic and Bcl-2 proteins are anti-apoptotic $(26,29)$. The results of ELISA demonstrated that ciprofloxacin significantly enhanced Bax expression in a concentration-dependent manner (Fig. 6B). Following treatment of MDA-MB-231 cells with $0.01,0.1$ and $1.0 \mu \mathrm{mol} / \mathrm{ml}$ ciprofloxacin for $24 \mathrm{~h}$, the expression of Bax increased by $35 \pm 4,56 \pm 3$ and $112 \pm 6 \%$, respectively, compared with the control (Fig. 6B). By contrast, the same concentrations of ciprofloxacin suppressed the expression of Bcl-2 by $8 \pm 1,10 \pm 2$ and $15 \pm 2 \%$, respectively, compared with the control (Fig. 6C). Consequently, the Bax/Bcl-2 ratio significantly increased following treatment with ciprofloxacin in a concentration-dependent manner (Fig. 6D).

Ciprofloxacin mediates $S$-phase arrest and DNA fragmentation in MDA-MB-231 cells. The impact of ciprofloxacin on the MDA-MB-231 breast cancer cell cycle was assessed using a fluorescence image cytometer. Based on the measurement of DNA content in individual cells from the cell population, the proportion of cells occupying the four main phases of the cell cycle was estimated (Fig. 7). Treatment with 0.01 and $0.1 \mu \mathrm{mol} / \mathrm{ml}$ ciprofloxacin for $24 \mathrm{~h}$ significantly increased the proportion of cells in the S-phase from $16 \pm 2 \%$ in the control to $20 \pm 2$ and $25 \pm 3 \%$, respectively (Fig. $7 \mathrm{~B}$ ). This indicates that ciprofloxacin induces S-phase arrest in MDA-MB-231 cells. Furthermore, ciprofloxacin induced DNA fragmentation, a late event in the apoptosis pathway. This phenomenon was only identified following treatment of cells with $1.0 \mu \mathrm{mol} / \mathrm{ml}$ ciprofloxacin, where the proportion of cells in the sub- $\mathrm{G}_{1}$ phase (having less than one DNA equivalent) significantly increased from $5 \pm 1$ to $78 \pm 3 \%$. Furthermore, there was a significant decrease in the proportion of cells in the $G_{1} / G_{0}$ and $\mathrm{G}_{2} / \mathrm{M}$ phases, from $66 \pm 2$ to $13 \pm 3 \%$ and from $13 \pm 2$ to $2 \pm 1 \%$, respectively.

\section{Discussion}

Breast cancer is the most common malignancy and the second most common cause of cancer-associated mortality among women worldwide (30). Current methods of treating breast cancer, such as chemotherapy, often cause the development of high systemic toxicity and drug resistance, leading to the therapeutic failure (3).

Fluoroquinolones are broad-spectrum synthetic antibiotics widely used to treat various infections (16). Certain members of these antibiotics exhibit antitumor activity in vitro in a number of different cancer cell lines $(12,13,15,31)$ and also in vivo (32). This antitumor activity was linked to the inhibition of the eukaryotic analogue of DNA gyrase, topoisomerase II $\alpha$ activity. To the best of our knowledge, the current study was the first to determine the impact of ciprofloxacin on cell viability, GSH levels, the apoptosis pathway and cell cycle distribution in human triple-negative MDA-MB-231 breast cancer cells.

Ciprofloxacin decreased the viability of MDA-MB-231 breast cancer cells in a time- and concentration-dependent manner. Following $24 \mathrm{~h}$ incubation with $0.01-1.0 \mu \mathrm{mol} / \mathrm{ml}$ ciprofloxacin, the viability of MDA-MB-231 decreased by $47 \%$ compared with the control. The cytotoxic effect intensified with the duration of incubation: $1.0 \mu \mathrm{mol} / \mathrm{ml}$ ciprofloxacin decreased the viability of MDA-MB-231 cells by 67 and 

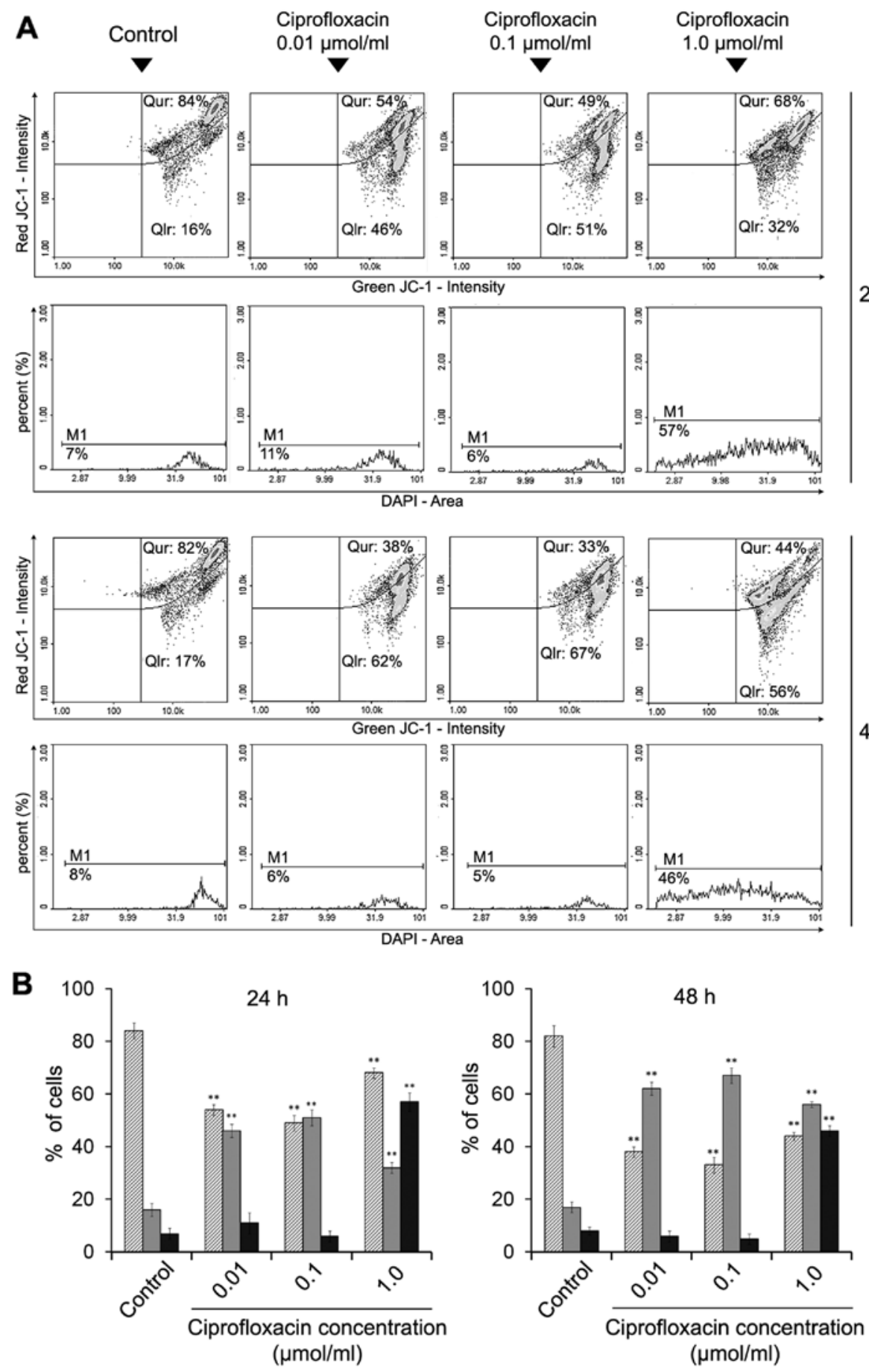

polarized (healthy) cells

depolarized (early apoptotic) cells

DAPI-positive (late apoptotic) cells

Figure 5. Ciprofloxacin disrupts the mitochondrial transmembrane potential in MDA-MB-231 cells and increases the number of late apoptotic cells. (A) Scatter plots presenting changes in JC-1 and DAPI intensity in MDA-MB-231 cells following treatment with $0.01,0.1$ and $1.0 \mu \mathrm{mol} / \mathrm{ml}$ ciprofloxacin for 24 and $48 \mathrm{~h}$. The presented graphs are representative of three independent experiments. (B) The effect of ciprofloxacin on the mitochondrial membrane potential and level of late apoptotic cells in the MDA-MB-231 cell line. Cells were treated with $0.01,0.1$ and $1.0 \mu \mathrm{mol} / \mathrm{ml}$ ciprofloxacin for 24 and $48 \mathrm{~h}$. All results are presented as the mean values \pm standard error of the mean from three independent experiments $(n=3)$ performed in triplicate. ${ }^{* *} \mathrm{P}<0.005$ vs. corresponding controls. Qur, mitochondrial membrane polarized (healthy) cells; Qlr, mitochondrial membrane depolarized (apoptotic) cells; M, DAPI-positive (late apoptotic) cells.

$74 \%$ compared with the control following incubation for 48 and $72 \mathrm{~h}$, respectively. Microscopic analysis indicated that MDA-MB-231 cells became rounded and lost their cell-cell contact following treatment with ciprofloxacin. Characteristic morphological features of apoptosis, including cell shrinkage, were also observed.

The cytotoxic effects of ciprofloxacin in A549 human non-small cell lung cancer, C6 rat glioblastoma and B16 mouse 

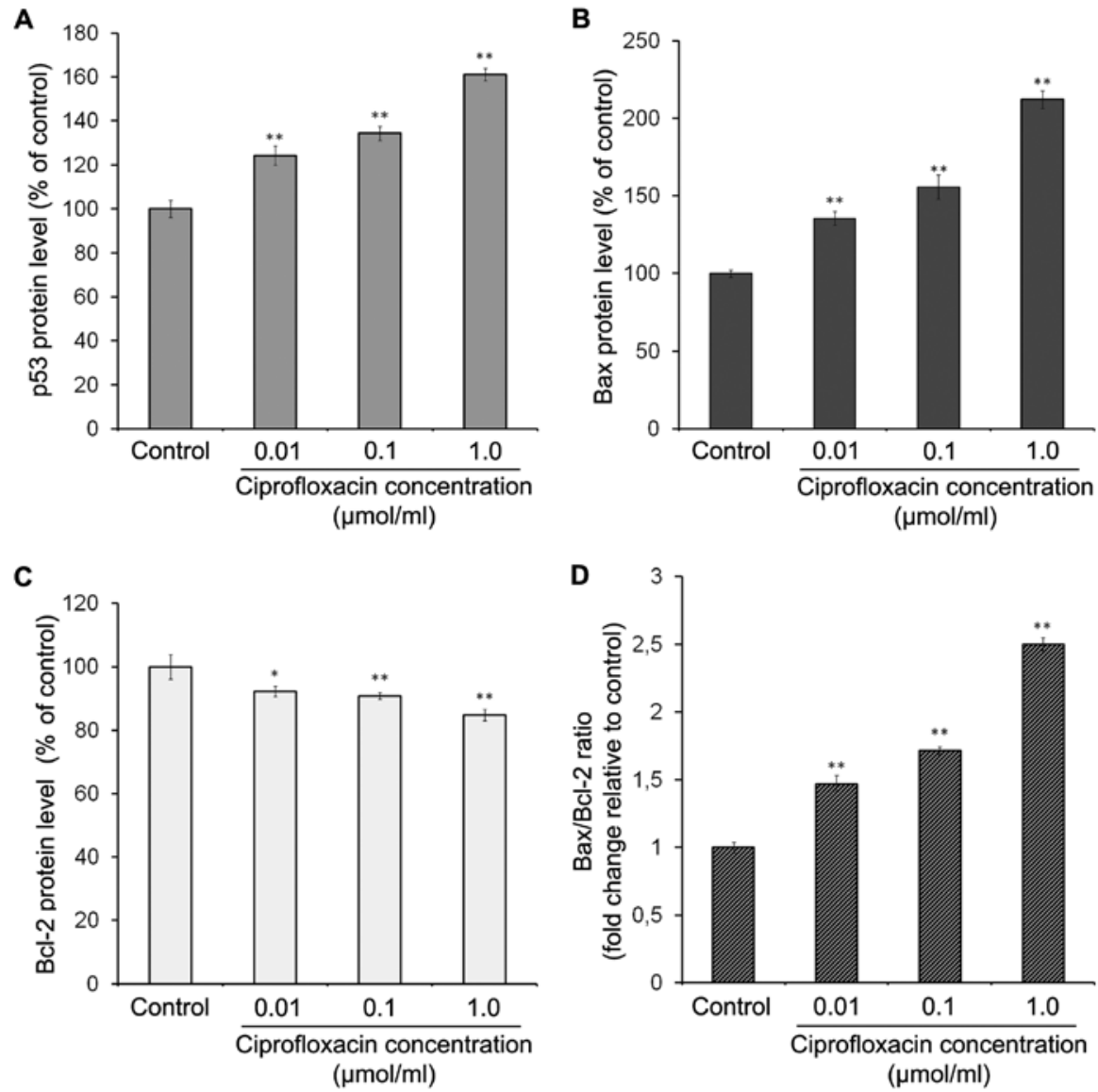

Figure 6. The effect of ciprofloxacin on the expression of (A) p53, (B) Bax and (C) Bcl-2 as well as the (D) Bax/Bcl-2 ratio in MDA-MB-231 cells. Cells were treated with $0.01,0.1$ and $1.0 \mu \mathrm{mol} / \mathrm{ml}$ ciprofloxacin for $24 \mathrm{~h}$. The results are presented as the mean values \pm standard error of the mean from three independent experiments ( $\mathrm{n}=3)$ performed in triplicate. ${ }^{*} \mathrm{P}<0.05$ and ${ }^{* *} \mathrm{P}<0.005$ vs. control.

melanoma cell lines were demonstrated by Kloskowski et al (31). The authors demonstrated that ciprofloxacin at concentrations of 0.4 and $0.3 \mu \mathrm{mol} / \mathrm{ml}$ (in A549 cells), 16.2 and $2.9 \mu \mathrm{mol} / \mathrm{ml}$ (in C6 cells), and 1.1 and $0.2 \mu \mathrm{mol} / \mathrm{ml}$ (in B16 cells) caused a $50 \%$ decrease in cell viability following 24 and $48 \mathrm{~h}$ incubation, respectively. The results of the present study detected a $50 \%$ decrease in the viability of MDA-MB-231 cells following 24 and $48 \mathrm{~h}$ incubation with $0.83 \mu \mathrm{mol} / \mathrm{ml}$ and $0.14 \mu \mathrm{mol} / \mathrm{ml}$ ciprofloxacin, respectively. This indicates that ciprofloxacin induces more cytotoxicity in TNBC MDA-MB-231 cells than in A549, C6 and B16 cells.

Previous studies have demonstrated that fluoroquinolones, including lomefloxacin (33), norfloxacin and moxifloxacin (34) and sparfloxacin (35) may alter the activity of the cellular antioxidant enzymes superoxide dismutase, catalase and GSH peroxidase. It has therefore been hypothesized that fluoroquinolones may induce cellular oxidative stress by triggering the generation of ROS, particularly the superoxide radical anion and hydrogen peroxide.

GSH, the most abundant cellular thiol and the primary determinant of cellular redox homeostasis, is an important mediator in apoptotic pathways $(36,37)$. Elevated GSH levels may disrupt apoptosis either by facilitating DNA repair or by buffering oxidative stress. Therefore, GSH depletion increases the sensitivity of cells to apoptosis induced by various chemical agents and radiation $(38,39)$. The present study examined whether the cytotoxic response of MDA-MB-231 cells following ciprofloxacin treatment may be associated with decreases in intracellular GSH levels. Ciprofloxacin at concentrations 0.1 and $1.0 \mu \mathrm{mol} / \mathrm{ml}$ caused 2- and 4-fold decreases in the proportion of cells exhibiting reduced GSH levels. These results suggest that ciprofloxacin may trigger apoptosis in MDA-MB-231 cells by decreasing intracellular thiol levels.

In the present study, Annexin V/PI double staining was performed to determined whether ciprofloxacin induces apoptosis in MDA-MB-231 breast cancer cells. The proportion of apoptotic cells,includingearly (Annexin V-positive/PI-negative) and late (Annexin V-positive/PI-positive) apoptotic cells, was increased following the exposure of cells to high concentrations of ciprofloxacin. A 4-fold increase in the proportion of apoptotic cells occurred following treatment with $1.0 \mu \mathrm{mol} / \mathrm{ml}$ ciprofloxacin.

To the best of our knowledge, there have been no previous studies investigating the effect of fluoroquinolones on human TNBC cells. It is hypothesized that fluoroquinolones inhibit bacterial type II topoisomerase (DNA gyrase), however there is also evidence to suggest that they may affect the viability of cells, including cancer cells (12,13,33-35). The anticancer activity of topoisomerase inhibitors may potentially occur via the inhibition of mitochondrial DNA synthesis, which subsequently induces mitochondrial injury, disorders in the respiratory chain and depletion of intracellular ATP stores. Energy depletion favors apoptosis, as it may induce cell cycle arrest in the $\mathrm{S}$ - and/or $\mathrm{G}_{2} / \mathrm{M}$ phases (26). 


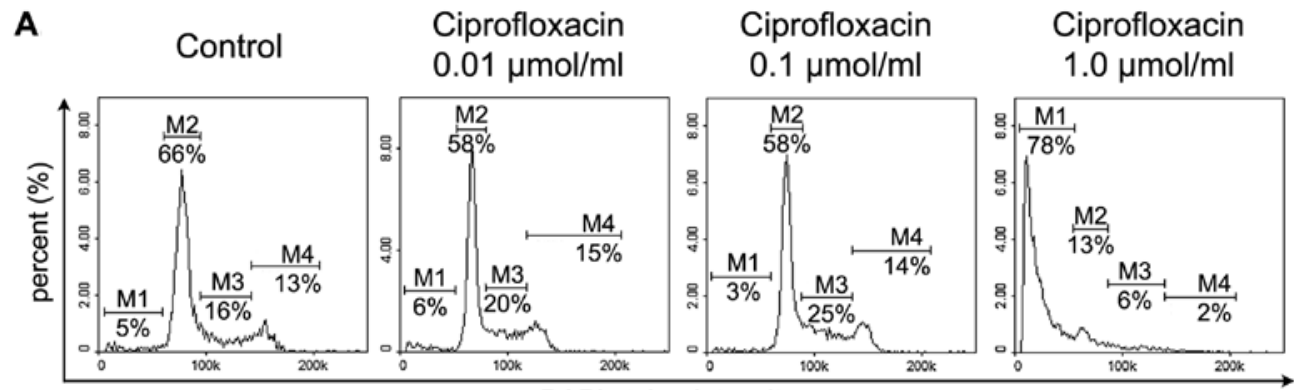

DAPI stain - Intensity

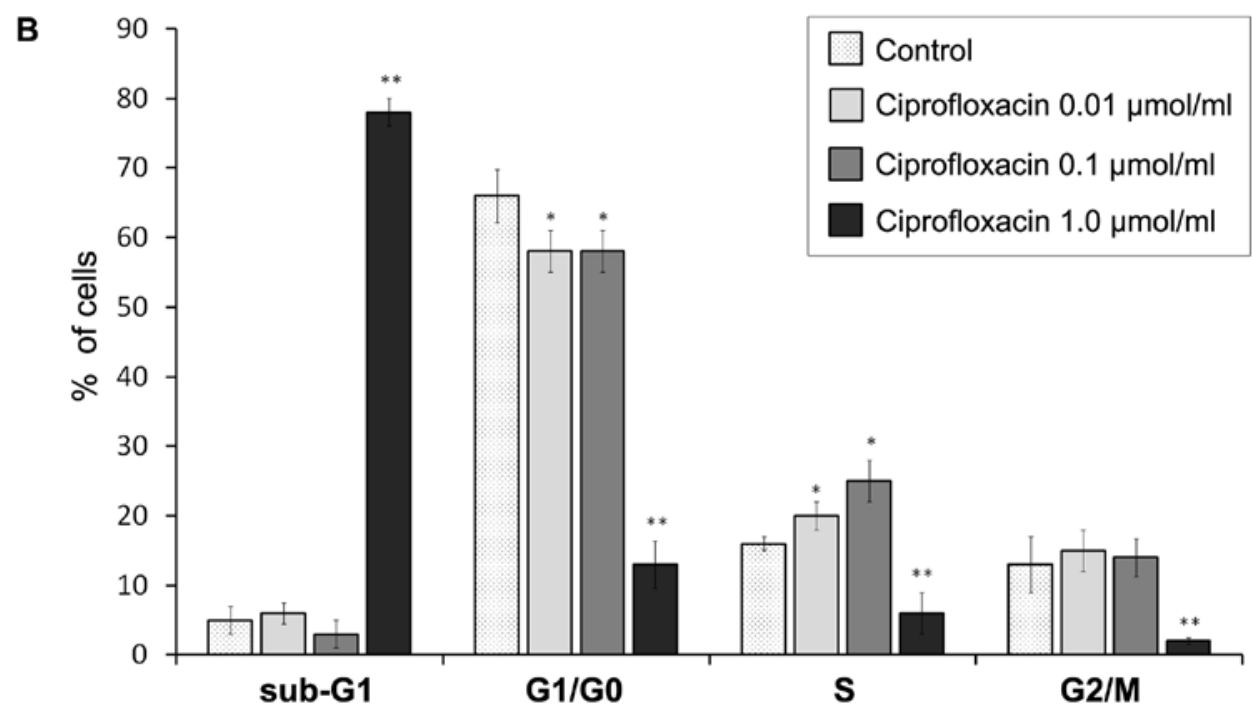

Figure 7. Ciprofloxacin induces S-phase arrest and DNA fragmentation in MDA-MB-231 cells. (A) Histograms presenting the cell cycle distribution in cells exposed to $0.01,0.1$ and $1.0 \mu \mathrm{mol} / \mathrm{ml}$ ciprofloxacin for $24 \mathrm{~h}$. The presented histograms are representative of three independent experiments. The effect of the ciprofloxacin on cell cycle distribution was determined using a fluorescence image cytometer following staining with DAPI. (B) The effect of ciprofloxacin on cell cycle distribution in MDA-MB-231 cells. Cells were treated with $0.01,0.1$ and $1.0 \mu$ mol/ml ciprofloxacin for $24 \mathrm{~h}$. The results are presented as the mean \pm standard error of the mean from three independent experiments $(\mathrm{n}=3)$ performed in triplicate are presented. ${ }^{*} \mathrm{P}<0.05$ and ${ }^{* *} \mathrm{P}<0.005$ vs. corresponding controls. $\mathrm{M} 1$, sub- $\mathrm{G}_{1}$ phase; $\mathrm{M} 2, \mathrm{G}_{1} / \mathrm{G}_{0}$ phase; $\mathrm{M} 3, \mathrm{~S}$-phase; $\mathrm{M} 4, \mathrm{G}_{2} / \mathrm{M}$ phase.

The present study investigated the mitochondria-associated events that occur during apoptosis in MDA-MB-231 cells following treatment with ciprofloxacin. It was demonstrated that ciprofloxacin induces apoptosis in breast cancer cells due to mitochondrial membrane breakdown. Treatment with $0.01,0.1$ and $1.0 \mu \mathrm{mol} / \mathrm{ml}$ ciprofloxacin for $24 \mathrm{~h}$ increased the proportion of depolarized/apoptotic cells by 30,35 and $16 \%$, respectively, compared with the control. This effect was more pronounced when the cells were treated with the drug for $48 \mathrm{~h}$; the proportion of depolarized/apoptotic cells reached $50 \%$. Furthermore, the proportion of late apoptotic cells increased following treatment with ciprofloxacin, reaching a peak following treatment with $1.0 \mu \mathrm{mol} / \mathrm{ml}$ ciprofloxacin for $24 \mathrm{~h}$. Similar results were obtained by Herold et al (11), where the cytotoxic response of human colorectal carcinoma cells to ciprofloxacin treatment was mediated by the mitochondrial apoptosis pathway.

It has been reported that one of the key responses of drug-induced DNA damage is the expression of p53 that leads to induction of apoptosis via the intrinsic mitochondrial pathway $(26,29)$. The results demonstrated that ciprofloxacin induces apoptosis in MDA-MB-231 cells and that this was accompanied by the upregulation of p53 expression. This suggests that the activation of p53 pathway may be involved in the apoptosis of MDA-MB-231 cells following treatment with ciprofloxacin. It was also observed that ciprofloxacin mediates the upregulation of Bax and downregulation of Bcl-2 expression, thus inducing apoptosis. Therefore, ciprofloxacin may stimulate the opening of the mitochondrial permeability transition pores via the Bax/Bcl-2-dependent pathway.

It has been demonstrated that cell cycle regulation is a method of regulating cell growth (26). Therefore, anticancer therapies may be used to block the cancer cell cycle. In the present study, fluorescence image cytometer analysis revealed that lower concentrations of ciprofloxacin $(0.01$ and $0.1 \mu \mathrm{mol} / \mathrm{ml})$ induced S-phase cell cycle arrest in MDA-MB-231 cells, suggesting that this occurs via topoisomerase II inhibition. It has been demonstrated by Kloskowski et al (31) that in human non-small lung cancer cells, ciprofloxacin induces cell cycle arrest at the $\mathrm{G}_{2} / \mathrm{M}$ checkpoint. Therefore, different molecular mechanisms of drug action may dominate depending on the cell type and origin. Furthermore, different molecular pathways may be activated by various fluoroquinolone derivatives in the same cell line (40).

The results of the Annexin V assay indicated that ciprofloxacin increased the proportion of apoptotic cells. To determine whether this increase was also triggered by apoptosis-associated DNA fragmentation, the induction of DNA fragmentation 
in MDA-MB-231 cells following exposure to ciprofloxacin was investigated. The highest concentration of ciprofloxacin (1.0 $\mathrm{mM}$ ) induced oligonucleosomal DNA fragmentation (the presence of sub- $\mathrm{G}_{1}$ fraction), strongly suggesting that apoptosis was induced via the p53-dependent pathway. These results are consistent with the results of our recent study, which revealed that ciprofloxacin mediates the induction of S-phase arrest and apoptosis in COLO829 melanoma cells (41). They are also consistent with the results of study by Yadav et al (13), which identified the ability of ciprofloxacin to induce DNA fragmentation and S-phase arrest in human pancreatic cancer cells.

Serum concentrations of ciprofloxacin in humans following two oral doses of $750 \mathrm{mg}$ are $\sim 10$-fold lower (42) than the concentrations that have a significant cytotoxic and pro-apoptotic effect on the MDA-MB-231 cell line. However, concentrations of ciprofloxacin in the targeted tissues may exceed those in the serum. Indeed, the concentration of ciprofloxacin following oral administration is up to 7 times higher in the lung tissue than in the serum (43). Furthermore, according to the results of our previous study, ciprofloxacin forms complexes with melanin and therefore this drug may accumulate in tissues containing high levels of melanin (44). Melanin biopolymers are present not only in the basal layer of the epidermis, but also in the outer parts of the breast, including the nipple and areola, hair follicles, uveal tract of the eye, the inner ear and central nervous system (45). In most cases of breast cancer in which the dermo-epidermal junction is breached, the accumulation of melanin within breast tumors may occur due to colonization by melanocytes, which are the cells responsible for melanin synthesis (46). Therefore, it is possible that ciprofloxacin concentrations in breast cancer cells may be significantly higher than in the serum and therefore a cytotoxic response, as well as the induction of apoptosis in the presence of this drug, may occur.

In conclusion, to the best of our knowledge, the present study is the first to indicate that ciprofloxacin induces concentrationand time-dependent decreases in human MDA-MB-231 breast cancer cell viability, induces apoptosis via the $\mathrm{p} 53 / \mathrm{Bax} / \mathrm{Bcl}-2$ signaling pathway and induces $\mathrm{S}$-phase cell cycle arrest. This suggests a mechanism of eukaryotic topoisomerase poisoning. The results of the present study provide important molecular data concerning the cellular cascade, which may explain the cytotoxic effects of ciprofloxacin on human TMBC cells and may provide a novel insight into the therapeutic properties of ciprofloxacin. Further in vivo studies are required to determine the potential use of ciprofloxacin to treat TNBC.

\section{Acknowledgements}

Not applicable

\section{Funding}

The present study was supported by the Medical University of Silesia Grant no. KNW-2-007/N/7/K.

\section{Availability of data and materials}

The analyzed data sets generated during the present study are available from the corresponding author on reasonable request.

\section{Author contributions}

AB conceived, designed, performed the experiments and wrote the paper; JR, performed the experiments, DW, ZR and MR performed the experiments and analyzed the data; EB conceived and designed the experiments. All authors have read and approved the final manuscript.

\section{Ethics approval and consent to participate}

Not applicable.

\section{Consent for publication}

Not applicable.

\section{Competing interests}

The authors declare that they have no competing interests.

\section{References}

1. Torre LA, Siegel RL, Ward EM and Jemal A: Global cancer incidence and mortality rates and trends-An update. Cancer Epidemiol Biomarkers Prev 25: 16-27, 2016.

2. Yao H, He G, Yan S, Chen C, Song L, Rosol TJ and Deng X: Triple-negative breast cancer: Is there a treatment on the horizon? Oncotarget 8: 1913-1924, 2017.

3. Anders C and Carey LA: Understanding and treating triplenegative breast cancer. Oncology (Williston Park) 22: 1233-1240, 1243,2008

4. Wahba HA and El-Hadaad HA: Current approaches in treatment of triple-negative breast cancer. Cancer Biol Med 12: 106-116, 2015.

5. Wang JC: Cellular roles of DNA topoisomerases: A molecular perspective. Nat Rev Mol Cell Biol 3: 430-440, 2002.

6. Tse-Dinh YC: Exploring DNA topoisomerases as targets of novel therapeutic agents in the treatment of infectious diseases. Infect Disord Drug Targets 7: 3-9, 2007.

7. Kaur P, Kaur V and Kaur S: DNA Topoisomerase II: promising target for anticancer drugs. In: Multi-Targeted Approach to Treatment of Cancer. Springer, pp323-338, 2015.

8. Cowell IG and Austin CA: Mechanism of generation of therapy related leukemia in response to anti-topoisomerase II agents. Int J Environ Res Public Health 9: 2075-2091, 2012.

9. Aldred KJ, Kerns RJ and Osheroff N: Mechanism of quinolone action and resistance. Biochemistry 53: 1565-1574, 2014.

10. Seo K, Holt R, Jung YS, Rodriguez CO Jr, Chen X and Rebhun RB: Fluoroquinolone-mediated inhibition of cell growth, S-G2/M cell cycle arrest, and apoptosis in canine osteosarcoma cell lines. PLoS One 7: e42960, 2012.

11. Herold C, Ocker M, Ganslmayer M, Gerauer H, Hahn EG and Schuppan D: Ciprofloxacin induces apoptosis and inhibits proliferation of human colorectal carcinoma cells. Br J Cancer 86: 443-448, 2002.

12. Yadav V, Sultana S, Yadav J and Saini N: Gatifloxacin induces $S$ and G2-phase cell cycle arrest in pancreatic cancer cells via p21/p27/p53. PLoS One 7: e47796, 2012.

13. Yadav V, Varshney P, Sultana S, Yadav J and Saini N: Moxifloxacin and ciprofloxacin induces S-phase arrest and augments apoptotic effects of cisplatin in human pancreatic cancer cells via ERK activation. BMC Cancer 15: 581, 2015.

14. Aranha O, Grignon R, Fernandes N, McDonnell TJ, Wood DP Jr and Sarkar FH: Suppression of human prostate cancer cell growth by ciprofloxacin is associated with cell cycle arrest and apoptosis. Int J Oncol 22: 787-794, 2003.

15. Aranha O, Wood DP Jr and Sarkar FH: Ciprofloxacin mediated cell growth inhibition, S/G2-M cell cycle arrest, and apoptosis in a human transitional cell carcinoma of the bladder cell line. Clin Cancer Res 6: 891-900, 2000.

16. Oliphant CM and Green GM: Quinolones: A comprehensive review. Am Fam Physician 65: 455-464, 2002. 
17. Talla V and Veerareddy P: Oxidative stress induced by fluoroquinolones on treatment for complicated urinary tract infections in Indian patients. J Young Pharm 3: 304-309, 2011.

18. Bisacchi GS and Hale MR: A 'Double-Edged' scaffold: Antitumor power within the antibacterial quinolone. Curr Med Chem 23: 520-577, 2016.

19. Arriola E, Marchio C, Tan DS, Drury SC, Lambros MB Natrajan R, Rodriguez-Pinilla SM, Mackay A, Tamber N, Fenwick K, et al: Genomic analysis of the HER2/TOP2A amplicon in breast cancer and breast cancer cell lines. Lab Invest 88: 491-503, 2008

20. Żaczek AJ, Markiewicz A, Seroczyńska B, Skokowski J, Jaśkiewicz J, Pieńkowski T, Olszewski WP, Szade J, Rhone P, Welnicka-Jaskiewicz M, et al: Prognostic significance of TOP2A gene dosage in HER-2-negative breast cancer. Oncologist 17: 1246-1255, 2012.

21. Shyur LF, Lee SH, Chang ST, Lo CP, Kuo YH and Wang SY: Taiwanin A inhibits MCF-7 cancer cell activity through induction of oxidative stress, upregulation of DNA damage checkpoint kinases, and activation of p53 and FasL/Fas signaling pathways. Phytomedicine 18: 16-24, 2010.

22. Panieri E and Santoro MM: ROS homeostasis and metabolism: A dangerous liason in cancer cells. Cell Death Dis 7: e2253, 2016.

23. Blaydes JP, Craig AL, Wallace M, Ball HM, Traynor NJ, Gibbs NK and Hupp TR: Synergistic activation of p53-dependent transcription by two cooperating damage recognition pathways. Oncogene 19: 3829-3839, 2000.

24. Burns TF and El-Deiry WS: The p53 pathway and apoptosis. J Cell Physiol 181: 231-239, 1999.

25. Pietenpol JA and Stewart ZA: Cell cycle checkpoint signaling: Cell cycle arrest versus apoptosis. Toxicology 181-182: 475-481, 2002.

26. Elmore S: Apoptosis: A review of programmed cell death. Toxicol Pathol 35: 495-516, 2007.

27. Chavez KJ, Garimella SV and Lipkowitz S: Triple negative breast cancer cell lines: One tool in the search for better treatment of triple negative breast cancer. Breast Dis 32: 35-48, 2010.

28. Beberok A, Wrześniok D, Szlachta M, Rok J, Rzepka Z, Respondek M and Buszman E: Lomefloxacin induces oxidative stress and apoptosis in COLO829 melanoma cells. Int J Mol Sci 18: E2194, 2017.

29. Bai L and Wang S: Targeting apoptosis pathways for new cancer therapeutics. Annu Rev Med 65: 139-155, 2014

30. Ferlay J, Soerjomataram I, Dikshit R, Eser S, Mathers C, Rebelo M, Parkin DM, Forman D and Bray F: Cancer incidence and mortality worldwide: Sources, methods and major patterns in GLOBOCAN 2012. Int J Cancer 136: E359-E386, 2015.

31. Kloskowski T, Gurtowska N, Olkowska J, Nowak JM, Adamowicz J, Tworkiewicz J, Dębski R, Grzanka A and Drewa T: Ciprofloxacin is a potential topoisomerase II inhibitor for the treatment of NSCLC. Int J Oncol 41: 1943-1949, 2012.

32. Thadepalli H, Salem F, Chuah SK and Gollapudi S: Antitumor activity of trovafloxacin in an animal model. In Vivo 19: 269-276, 2005 .
33. Beberok A, Buszman E, Otręba M and Wrześniok D: Impact of lomefloxacin on antioxidant enzymes activity in normal melanocytes HEMa-LP. Curr Issues Pharm Med Sci 25: 426-429, 2012.

34. Beberok A, Wrześniok D, Otręba M, Miliński M, Rok J and Buszman E: Effect of norfloxacin and moxifloxacin on melanin synthesis and antioxidant enzymes activity in normal human melanocytes. Mol Cell Biochem 401: 107-114, 2015.

35. Beberok A, Wrześniok D, Otręba M and Buszman E: Impact of sparfloxacin on melanogenesis and antioxidant defense system in normal human melanocytes HEMa-LP - An in vitro study. Pharmacol Rep 67: 38-43, 2015.

36. Liou GY and Storz P: Reactive oxygen species in cancer. Free Radic Res 44: 479-496, 2010.

37. Hall AG: Review: The role of glutathione in the regulation of apoptosis. Eur J Clin Invest 29: 238-245, 1999.

38. Mirkovic N, Voehringer DW, Story MD, McConkey DJ, McDonnell TJ and Meyn RE: Resistance to radiation-induced apoptosis in Bcl-2-expressing cells is reversed by depleting cellular thiols. Oncogene 15: 1461-1470, 1997.

39. Dai J, Weinberg RS, Waxman S and Jing Y: Malignant cells can be sensitized to undergo growth inhibition and apoptosis by arsenic trioxide through modulation of the glutathione redox system. Blood 93: 268-277, 1999.

40. Blau H, Klein K, Shalit I, Halperin D and Fabian I: Moxifloxacin but not ciprofloxacin or azithromycin selectively inhibits IL-8, IL-6, ERK1/2, JNK, and NF-kappaB activation in a cystic fibrosis epithelial cell line. Am J Physiol Lung Cell Mol Physiol 292: L343-L352, 2007.

41. Beberok A, Wrześniok D, Minecka A, Rok J, Delijewski M, Rzepka Z, Respondek M and Buszman E: Ciprofloxacinmediated induction of S-phase cell cycle arrest and apoptosis in COLO829 melanoma cells. Pharmacol Rep 70: 6-13, 2017.

42. Shah A, Lettieri J,Kaiser L, Echols R and Heller AH: Comparative pharmacokinetics and safety of ciprofloxacin $400 \mathrm{mg}$ i.v. thrice daily versus $750 \mathrm{mg}$ po twice daily. J Antimicrob Chemother 33: 795-801, 1994

43. Rohwedder R, Bergan T, Caruso E, Thorsteinsson SB, Della Torre $\mathrm{H}$ and Scholl H: Penetration of ciprofloxacin and metabolites into human lung, bronchial and pleural tissue after 250 and $500 \mathrm{mg}$ oral ciprofloxacin. Chemotherapy 37: 229-238, 1991.

44. Beberok A, Buszman E, Wrześniok D, Otręba $M$ and Trzcionka J: Interaction between ciprofloxacin and melanin: The effect on proliferation and melanization in melanocytes. Eur J Pharmacol 669: 32-37, 2011.

45. d'Ischia M, Wakamatsu K, Cicoira F, Di Mauro E, GarciaBorron JC, Commo S, Galván I, Ghanem G, Kenzo K, Meredith P, et al: Melanins and melanogenesis: From pigment cells to human health and technological applications. Pigment Cell Melanoma Res 28: 520-544, 2015.

46. Wyatt AJ, Agero ALC, Delgado R, Busam KJ and Marghoob AA: Cutaneous metastatic breast carcinoma with melanocyte colonization: A clinical and dermoscopic mimic of malignant melanoma. Dermatol Surg 32: 949-954, 2006. 